\title{
Rozmieszczenie i zróżnicowanie przestrzenne terenów przemysłowych w województwie mazowieckim na tle rozmieszczenia i zróżnicowania przestrzennego terenów przemysłowych w Polsce
}

\section{Marta Borowska-Stefańska, Szymon Wiśniewski}

\begin{abstract}
STRESZCZENIE
W artykule dokonano analizy rozmieszczenia i oceny zróżnicowania terenów przemysłowych w Polsce pod względem ich cech geometrycznych. Obliczono m.in. ich powierzchnię i liczbę według województw oraz jednostek ewidencyjnych, udział w poszczególnych jednostkach ewidencyjnych, średnią powierzchnię według jednostek ewidencyjnych, wskaźnik zróżnicowania kształtu działki, wskaźnik zwartości kształtu działki. Dane odnoszące się do cech geometrycznych omawianych terenów w skali kraju, zestawiono z tymi dla województwa mazowieckiego. Dane na temat terenów przemysłowych w Polsce zaczerpnięto z Bazy Danych Obiektów Topograficznych (BDOT), którą pozyskano z Centralnego Ośrodka Dokumentacji Geodezyjnej i Kartograficznej w Warszawie. Warstwy z działkami pochodzą natomiast z systemu LPIS (System identyfikacji działek rolnych). Tereny przemysłowe w Polsce są zróżnicowane pod względem okoliczności i czasu powstania, zasięgu, zagospodarowania, prowadzonej działalności i relacji łączących je z otoczeniem gospodarczym. W ujęciu przestrzennym, przeprowadzone badania wskazują że rozmieszczenie terenów związanych z działalnością przemysłową w Polsce cechuje się dużym zróżnicowaniem. Zdecydowanie największa powierzchnia terenów przemysłowych znajduje się w województwie śląskim, mazowieckim i wielkopolskim. Przeciętna powierzchnia terenów przemysłowych jest najwyższa w aglomeracji górnośląskiej, w województwie mazowieckim oraz w województwie zachodniopomorskim. Ponadto zaznacza się różnica pomiędzy zachodnią, a wschodnią Polską. W części zachodniej kraju, tereny na których prowadzona jest działalność przemysłowa są zdecydowanie większe. Liczba terenów przemysłowych jest najwyższa w szczególności w gminach województwa śląskiego, mazowieckiego i wielkopolskiego. Z kolei porównując dane dotyczące terenów przemysłowych w skali kraju, z tymi w województwie mazowieckim, stwierdzono, że różnice są dostrzegalne w przypadku średniej powierzchni terenów przemysłowych - jest ona nieznacznie wyższa w województwie mazowieckim, gdzie wynosi ok. 0,9 ha oraz średniej liczby terenów przemysłowych - jest ona niższa w przypadku badanego regionu. Wartości te mają swoje odzwierciedlenie również w przypadku średniej wartości wskaźnika zróżnicowania kształtu badanych terenów - jest on prawie dwukrotnie niższy w analizowanym regionie. Z kolei średni udział terenów przemysłowych oraz średnia wartość wskaźnika zwartości działki jest w obu przypadkach na porównywalnym poziomie.
\end{abstract}

Słowa kluczowe: Polska, tereny przemysłowe, geografia przemysłu, GIS

\section{Wprowadzenie}

Zmiany, jakie nastąpiły w Polsce po 1989 r., polegały na przejściu od gospodarki centralnie planowanej do rynkowej, najsilniej zaznaczyły się w skupiskach miejskich [Liszewski 2004; Rachwał 2008; Trojak, Wiedermann 2009; Cudny 2011]. W szczególności dotyczyły one jednak przemysłu [Marczyńska-Witczak 2001; Marczyńska-Witczak, Starzyńska 2002; Domański 2006]. Sprzyjały one a jednocześnie wymuszały głęboką restrukturyzacją i modernizację 
wszystkich struktur przemysłowych tj. własnościowa, organizacyjna, wielkościowa, asortymentową. Oczywiście, poza czynnikami politycznymi i ekonomicznymi, stymulantami tych przemian były nowe technologie i techniki wytwarzania [Marczyńska-Witczak 2001; Marczyńska-Witczak, Starzyńska 2002]. Proces transformacji systemowej w Polsce pociągnął za sobą zmiany w rozmieszczeniu i dostępności do czynników produkcji, różnych zasobów oraz do miejsc zaopatrzenia surowcowo-materiałowego i rynków zbytu [Rachwał 2010]. Skutkiem tego było lokowanie nowych rodzajów produkcji w nowych obszarach świata, regionu czy też miasta [Marczyńska-Witczak 2001; Marczyńska-Witczak, Starzyńska 2002]. Procesy gospodarcze zainicjowane po 1989 r. doprowadziły do powstawania przestrzennych skupień przedsiębiorstw i przyczyniły się do szybkiego rozwoju gospodarczego pewnych obszarów przy jednoczesnej stagnacji bądź recesji związanej z upadkiem podmiotów gospodarczych, stanowiących bazę ekonomiczną miast i regionów.

W obecnej sytuacji niezwykle ważna jest identyfikacja obszarów stagnujących, w obrębie których nie rozwijają się nowe formy działalności gospodarczej. Tylko właściwa diagnoza przyczyn tego zjawiska, umożliwia podjęcie działań, których celem jest zwiększenie atrakcyjności tych obszarów na potrzeby nowych inwestorów. Jest to w szczególności ważne, w przypadku terenów o monofunkcyjnej bazie ekonomicznej, związanej z rozwojem dużych kombinatów przemysłowych. Firmy przemysłowe generują rozwój gospodarczy regionu poprzez efekty mnożnikowe. Jednym z takich sposobów jest tworzenie przywilejów dla firm działających na tego typu obszarach [Trojak, Wiedermann 2009]. W wyniku tego procesu, w Polsce na początku lat 90. XX w., powstała idea tworzenia specjalnych stref ekonomicznych, która miała na celu wspieranie rozwoju gospodarczego pewnych obszarów poprzez przyciąganie dużych przedsiębiorstw przemysłowych [Kryńska 2000; Smętkowski 2008].

Przestrzeń przemysłowa w Polsce jest częścią przestrzeni gospodarczej, ukształtowaną w okresie długiego doświadczenia historycznego. Jej aktualny stan to wynik różnorodnych wydarzeń społecznych oraz gospodarczych. Do podstawowych elementów przestrzeni przemysłowej należą różnorodne formy koncentracji przemysłu, które stanowią funkcję natężenia sił skupienia przestrzennego potencjału produkcyjnego i czasu. Skupiska przemysłowe są zróżnicowane pod względem genezy, zasięgu, zainwestowania, struktury produkcji, powiązań techniczno-ekonomicznych itd. W literaturze podmiotu panuje pogląd, że podstawowym elementem koncentracji przemysłu jest zakład przemysłowy, natomiast najwyższą formą koncentracji działalności przemysłowej jest okręg przemysłowy [Gierańczyk, Stańczyk 2001]. Badania nad hierarchizacją i określaniem poszczególnych typów przestrzennych form koncentracji przemysłu prowadzili m.in. I. Fierla 1984, 1987, S. Misztal 1970, L. Pakuła 1978, K. Secomski 1956, Z. Zioło 1971, W. Gierańczyk, A. Stańczyk 2001.

W niniejszym artykule dokonano analizy rozmieszczenia i oceny zróżnicowania terenów przemysłowych w Polsce pod względem ich cech geometrycznych. Dane odnoszące się do cech geometrycznych omawianych terenów w skali kraju, zestawiono z tymi dla województwa mazowieckiego. 


\section{Metody badawcze i materiały źródłowe}

Dane na temat terenów przemysłowych w Polsce zaczerpnięto z Bazy Danych Obiektów Topograficznych (BDOT), którą pozyskano z Centralnego Ośrodka Dokumentacji Geodezyjnej i Kartograficznej w Warszawie. Warstwy z działkami pochodzą natomiast z systemu LPIS (System identyfikacji działek rolnych), [Borowska-Stefańska i in. 2017 a; Borowska-Stefańska i in. 2017 b]. Za teren przemysłowy uznano w artykule obszar, którego pokrycie terenu zgodnie z BDOT zostało opisane kodem PTZB03 (zabudowa przemysłowoskładowa) lub PTNZ02 (teren przemysłowo-składowy).

Tereny przemysłowe scharakteryzowano ze względu na ich cechy geometryczne. Obliczono m.in. ich powierzchnię i liczbę według województw oraz jednostek ewidencyjnych, udział w poszczególnych jednostkach ewidencyjnych, średnią powierzchnię według jednostek ewidencyjnych, wskaźnik zróżnicowania kształtu działki, wskaźnik zwartości kształtu działki. W celu zbadania kształtu działek w jednostkach ewidencyjnych wykorzystano pomiary długości ich granic i powierzchnię. Zastosowano przy tym dwa mierniki tego kształtu, opracowane przez J. Dzieciuchowicza [Dzieciuchowicz, Dmochowska-Dudek 2014] Pierwszy z nich, określający zróżnicowanie kształtu, stanowi stosunek przeciętnej długości granic działek (dj) do ich średniej powierzchni w danej jednostce ewidencyjnej (pj):

$$
\mathrm{Kzj}=\operatorname{dj} / \mathrm{pj} \times 100
$$

Im więcej odcinków o zróżnicowanych kierunkach ma granica działki, tym większa jej długość przypada na jednostkę powierzchni gruntu. Omawiany wskaźnik wzrasta tym samym w ślad za rosnącym urozmaiceniem kształtu działek w określonych jednostkach terytorialnych.

Drugi, wykorzystany w pracy wskaźnik (zwartości), określa stosunekśredniej rzeczywistej długości granic działek (dj) w danej jednostce ewidencyjnej do hipotetycznej długości tych granic Lj, która odpowiada długości obwodu koła, gdyby miało ono powierzchnię równą średniej powierzchni rzeczywistej działek tej jednostki:

$$
\mathrm{Khj}=\mathrm{dj} / \mathrm{Lj}
$$

gdzie $\mathrm{Lj}=2 \pi \mathrm{r}$, dla koła o średniej powierzchni działek $\mathrm{w}$ gminach $\mathrm{j}$.

Zastosowany wskaźnik wyraża stopień, w jakim rzeczywisty kształt działek różni się od koła. Jego wartości wzrastają proporcjonalnie do wskazanej różnicy. Jednocześnie wzrost ten odzwierciedla spadek zwartości terytorialnej działek. Określa on zarazem, w jakim stopniu rzeczywista średnia długość granicy działek w danej jednostce ewidencyjnej, różni się od minimalnej długości równej długości obwodu koła odpowiadającego przeciętnej powierzchni działek tej jednostki [Dzieciuchowicz, Dmochowska-Dudek 2014; BorowskaStefańska i in. 2017 a; Borowska-Stefańska i in. 2017 b].

$\mathrm{Na}$ koniec przedstawiono natomiast wymienione wcześniej cechy terenów przemysłowych jedynie w odniesieniu do województwa mazowieckiego.

Do przeprowadzenia wszystkich analiz niezbędne było wykorzystanie narzędzi GIS [Borowska-Stefańska, Wiśniewski 2017]. 
Ryc. 1. Rozmieszczenie terenów przemysłowych w Polsce w 2016 r.

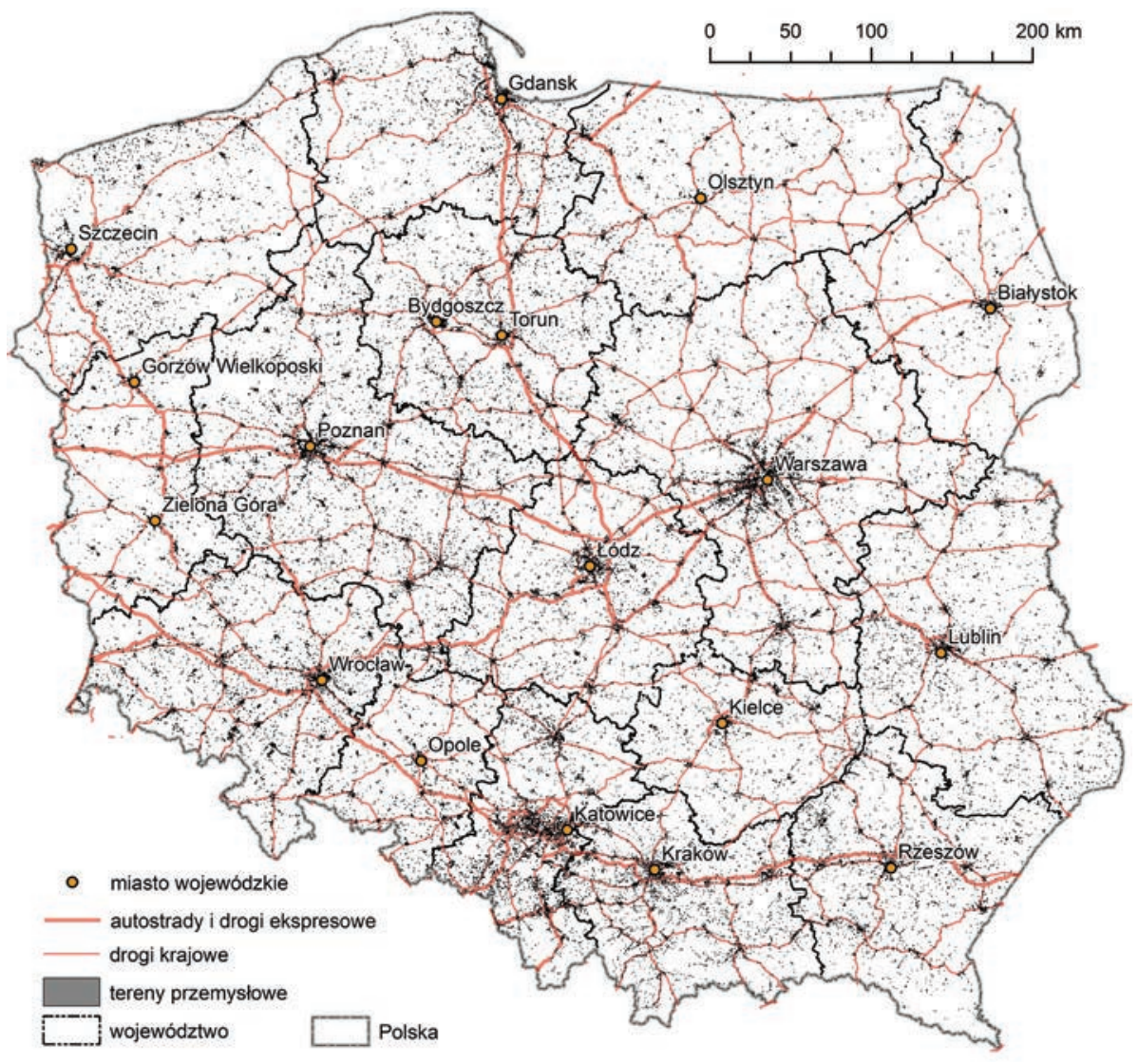

Źródło: opracowanie własne na podstawie BDOT

Wyniki i dyskusja

Badania nad rozmieszczeniem przemysłu w Polsce mają bogatą tradycję, stworzoną jeszcze w latach 60. i 70. XX w. Prowadzili je m.in. S. Leszczycki i in. [1964], W. Kawalec [1970]. W wyniku tych badań stwierdzono, że przestrzenna struktura przemysłu cechuje się wysokim stopniem koncentracji oraz istnieniem silnego centrum przemysłowego w aglomeracji górnośląskiej. Uzupełnieniem tego były rozwijające się aglomeracje miejskoprzemysłowe m.in.: Warszawy, Łodzi, Trójmiasta, Poznania, Szczecina, Krakowa czy Wrocławia [Smętkowski 2008]. Pod koniec lat 90. XX w. w Polsce dominowały trzy okręgi: warszawski, górnośląsko-bielski oraz wielkopolski (poznański i kaliski). Te trzy przestrzenie stanowiły wierzchołki trójkąta przemysłowego Polski, którego środek wypełniał czwarty pod względem znaczenia, łódzki okręg przemysłowy. Pozostałe obszary przemysłowe miały 


\section{Ryc. 2. Całkowita powierzchnia i liczba terenów przemysłowych wg województw w Polsce w 2016 r.}

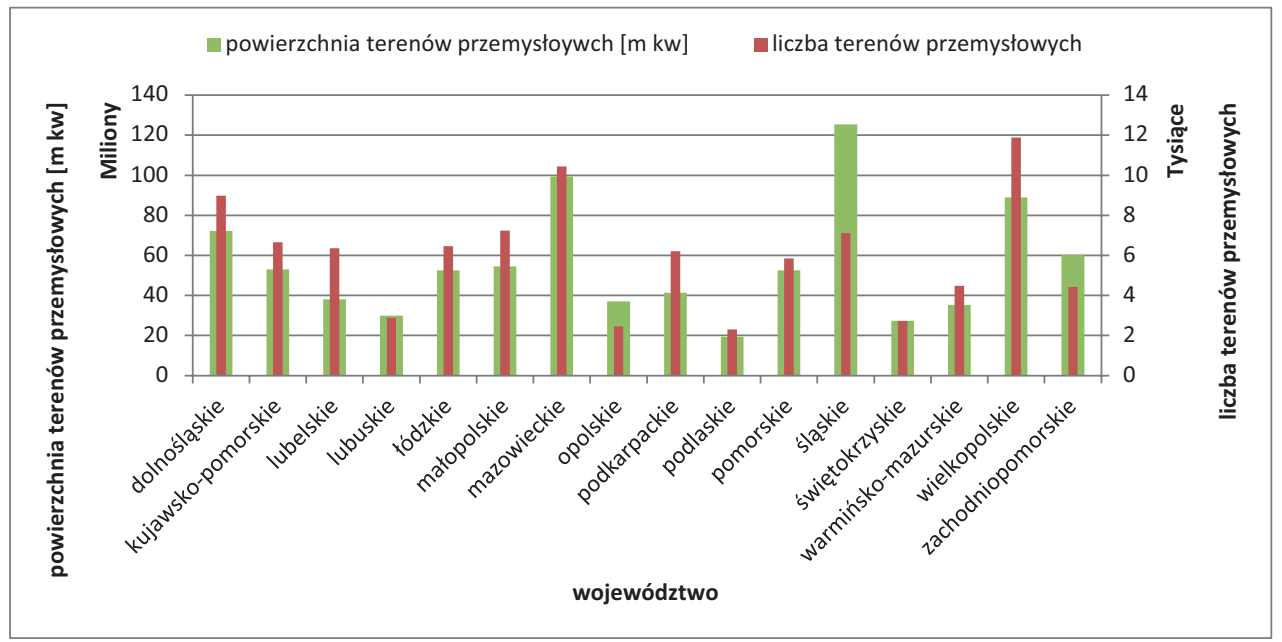

Źródło: opracowanie własne na podstawie BDOT

charakter peryferyjny w stosunku do omówionego trójkąta przemysłowego. Były to głównie obszary industrialne, utworzone w stolicach nowych województw. Struktura przemysłowa Polski cechowała się zatem dużą inercją przy jednoczesnym kurczeniu się jej powierzchni [Gierańczyk, Stańczyk 2001]. Jak stwierdził M. Smętkowski [2008] rozmieszczenie przemysłu w Polsce cechuje się dużym zróżnicowaniem regionalnym i subregionalnym. Zaznacza się zwłaszcza zróżnicowanie pomiędzy dużymi ośrodkami miejskimi i ich najbliższym otoczeniem a obszarami wiejskimi oraz pomiędzy zachodnią i wschodnią częścią Polski (ryc. 1). Również obecnie (stan na dzień 20.07.2015 r.) największa powierzchnia terenów przemysłowych znajduje się w województwie śląskim, mazowieckim oraz wielkopolskim (ryc. 1, ryc. 2) i wynosi ona odpowiednio: 12536, 3 ha, 9929, 4 ha i 8886,5 ha. Z kolei najmniej omawianych terenów znajduje się w województwie podlaskim, a ich powierzchnia wynosi 1928,7 ha.

Największa powierzchnia (wynosząca od 1754,7 ha w Warszawie do 305,8 ha w Olsztynie) oraz udział terenów przemysłowych (wynoszący od 5,3\% w Katowicach do 1,1\% w Zielonej Górze) przypada na stolice wojewódzkie oraz obszary będące w ich najbliższym otoczeniu, co potwierdza, że odznaczają się one stabilnością pod względem ich występowania [Gierańczyk, Stańczyk 2001], (ryc. 3, ryc. 4).

Jak już wcześniej wspomniano, w Polsce od lat 90. XX w. powstają Specjalne Strefy Ekonomiczne (SSE), (pierwszą utworzono w 1995 r. - zlokalizowano ją na terenie Mielca SSE Euro-Park Mielec) [Trojak, Wiedermann 2009]. SSE to „administracyjnie wyodrębnione obszary kraju, które oferuja przedsiębiorcom preferencyjne warunki prowadzenia dziatalności gospodarczej (zwolnienia od podatku dochodowego; w niektórych przypadkach gminnego podatku od 
Ryc. 3. Udział powierzchni terenów przemysłowych w całkowitej powierzchni jednostek ewidencyjnych w Polsce w 2016 r.

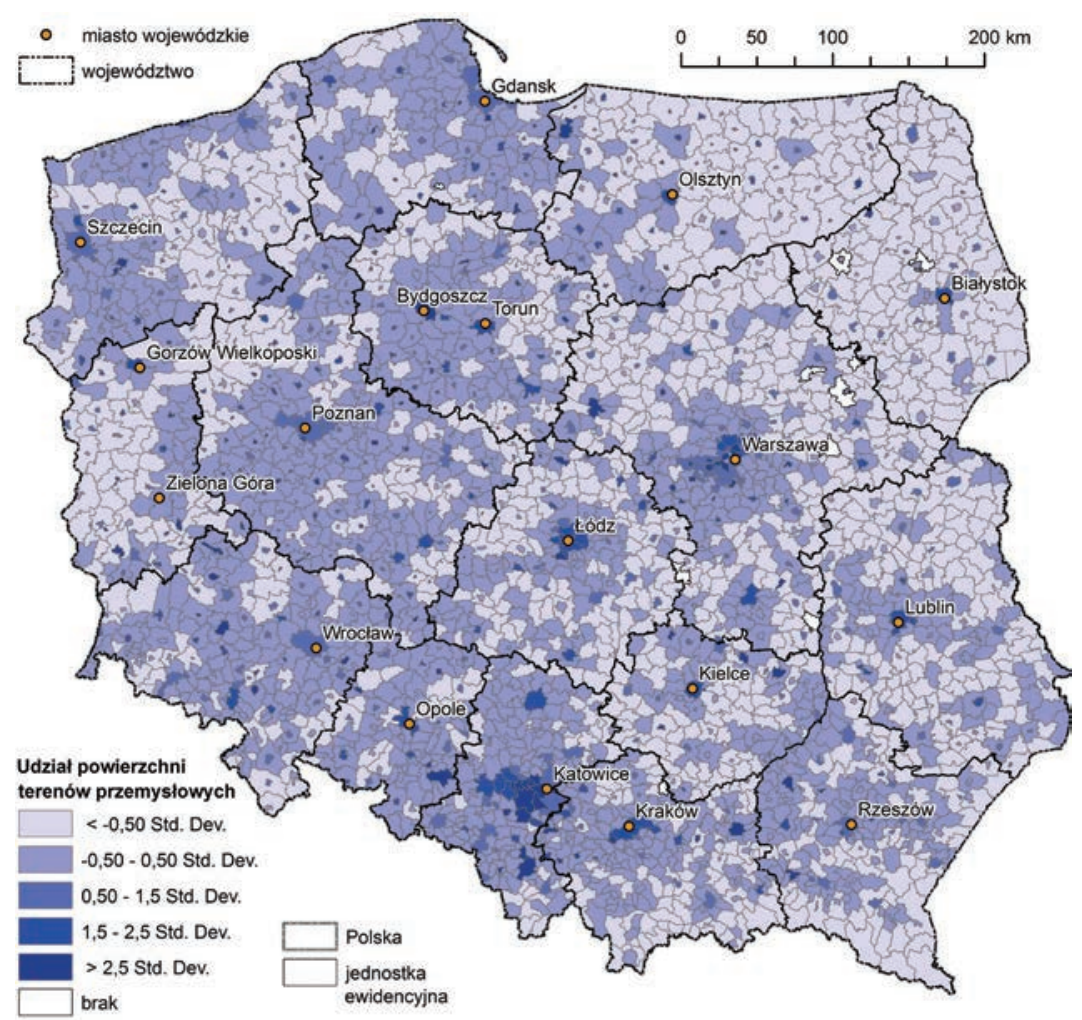

Źródło: opracowanie własne na podstawie BDOT

nieruchomości; dostęp do infrastruktury; wsparcie administracyjne)" [Trzciński i in. 2016, s. 3]. Były one początkowo lokalizowane na terenach poprzemysłowych, z wysokim poziomem bezrobocia oraz rozbudowaną infrastrukturą przemysłową. Działania te były łatwiejsze do zastosowania w początkowym okresie ich funkcjonowania, kiedy to SSE traktowano jako narzędzie do wspierania zrównoważonego rozwoju regionów szczególnie dotkniętych skutkami transformacji gospodarczej. Z biegiem czasu kryteria te uległy jednak modyfikacji, gdy te najbardziej atrakcyjne tereny inwestycyjne udało się wykorzystać. Wówczas podstrefy SSE zaczęto tworzyć w obrębie dużych miast oraz dynamicznie rozwijających się gmin [Trzciński i in. 2016].

Ponadto, analiza powierzchni terenów przemysłowych w gminach wiejskich i miejskich potwierdza ich zróżnicowanie [Smętkowski 2008]. Omawiane obszary zdecydowanie dominują w miastach, zarówno pod względem średniej - ok. 1,2 ha, jak i ogólnej ich powierzchni - 39793 ha (tabela 1). 
Ryc. 4. Zróżnicowanie powierzchni terenów przemysłowych wg jednostek ewidencyjnych w Polsce w 2016 r.

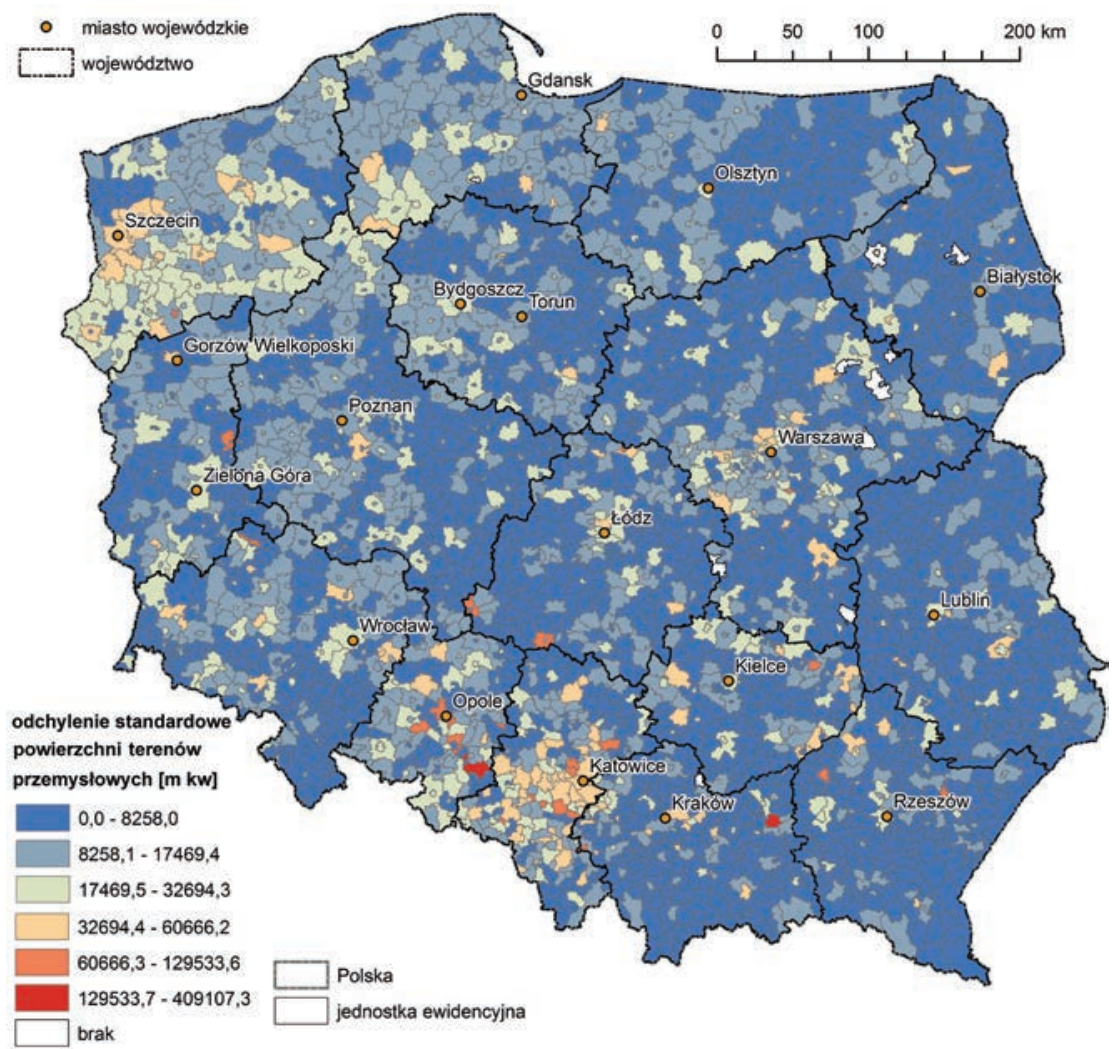

Źródło: opracowanie własne na podstawie BDOT

Tabela 1. Charakterystyka terenów przemysłowych wg typów jednostek ewidencyjnych w Polsce w 2016 r.

\begin{tabular}{|c|c|c|c|c|c|c|c|}
\hline $\begin{array}{c}\text { Jednostka } \\
\text { ewidencyjna }\end{array}$ & $\begin{array}{c}\text { Liczba } \\
\text { terenów }\end{array}$ & $\begin{array}{c}\text { Udział } \\
\text { (\%) }\end{array}$ & $\begin{array}{c}\text { Średnia } \\
\text { pow. } \\
\text { (ha) }\end{array}$ & $\begin{array}{c}\text { Całkowita } \\
\text { pow. } \\
\text { (ha) }\end{array}$ & $\begin{array}{c}\text { Udział } \\
\text { (\%) }\end{array}$ & $\begin{array}{c}\text { Odchylenie } \\
\text { standardowe } \\
\text { pow. (ha) }\end{array}$ & $\begin{array}{c}\text { Średni udział } \\
\text { w całkowitej } \\
\text { pow. obszaru } \\
\text { (\%) }\end{array}$ \\
\hline Gm. miejska & 32714 & 33,9 & 1,22 & 39793,83 & 44,9 & 4,06 & 2,9 \\
\hline Gm. wiejska & 34515 & 35,8 & 0,68 & 23587,89 & 26,6 & 1,16 & 0,7 \\
\hline $\begin{array}{c}\text { Miasto w gminie } \\
\text { miejsko-wiejskiej }\end{array}$ & 14485 & 15,0 & 0,92 & 13387,38 & 15,1 & 2,15 & 9,3 \\
\hline $\begin{array}{c}\text { Obszar wiejski } \\
\text { w gminie } \\
\text { miejsko-wieskiej }\end{array}$ & 14735 & 15,3 & 0,81 & 1193,37 & 13,5 & 1,63 & 0,6 \\
\hline
\end{tabular}

Źródło: opracowanie własne na podstawie BDOT 
Ryc. 5. Średnia powierzchnia terenu przemysłowego wg jednostek ewidencyjnych w Polsce w 2016 r.

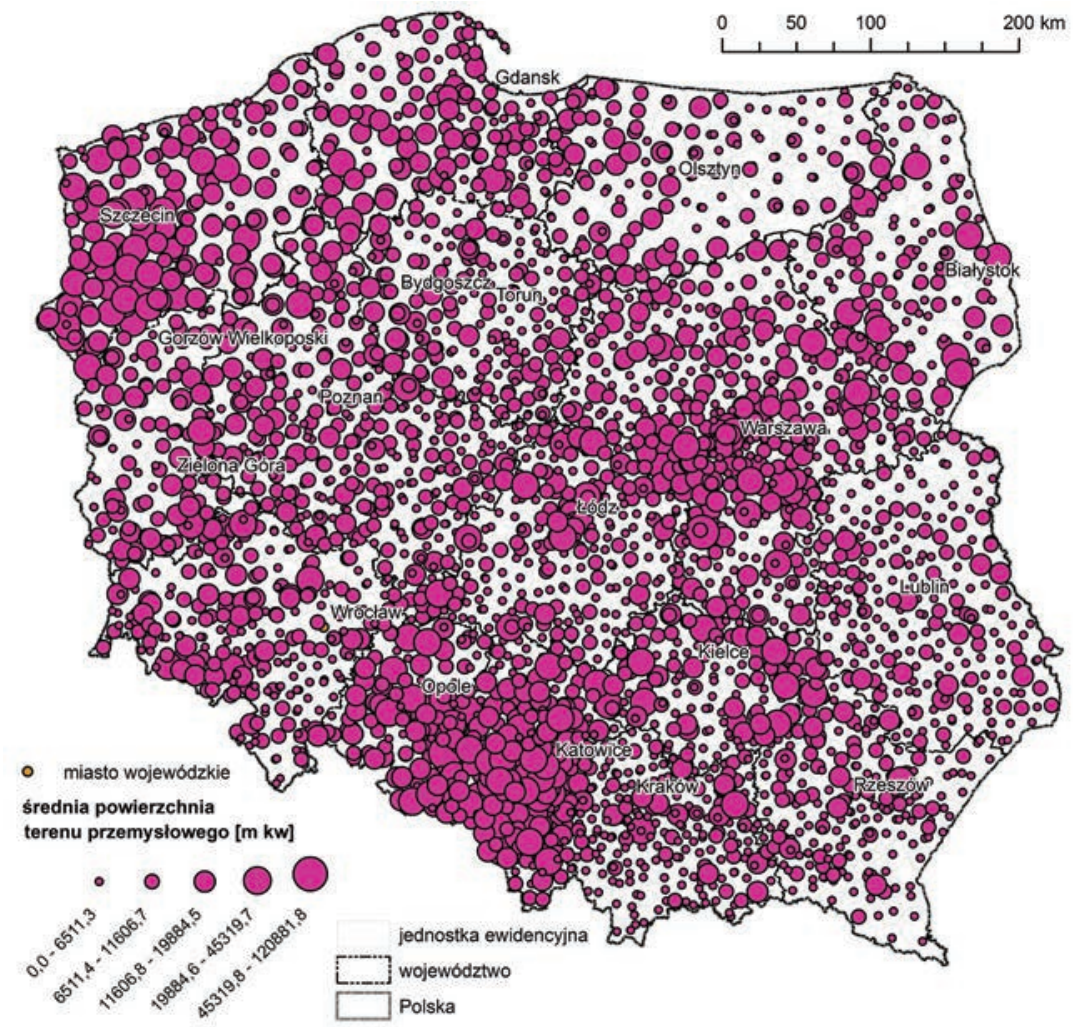

Źródło: opracowanie własne na podstawie BDOT

Średnia powierzchnia terenów przemysłowych jest najwyższa w aglomeracji górnośląskiej (gdzie wynosi 1,9 ha), w województwie zachodniopomorskim (1,3 ha) oraz w województwie mazowieckim (0,9 ha). Ponadto zaznacza się różnica pomiędzy zachodnia, a wschodnią Polską - na zachodzie omawiane obszary są zdecydowanie większe (ich średnia powierzchnia wynosi 0,9 ha), (ryc. 5). Na brak wyraźnych obszarów przemysłowych w szczególności w regionie północno-wschodnim, w województwach podlaskim i warmińsko-mazurskim oraz w tzw. „ścianie wschodniej” wskazywali W. Gierańczyk i A. Stańczyk [2001] - sytuacja ta pozostała niezmienna. Są to obszary, gdzie stopa bezrobocia rejestrowanego jest wysoka - dla przykładu w województwie warmińsko-mazurskim wynosi ona 16,2 (stan z 2015 r., www.stat.gov.pl). Są to najmniej atrakcyjne inwestycyjnie obszary.

Ponadto, jak już wcześniej zauważono, również liczba terenów przemysłowych jest najwyższa w szczególności w gminach województwa śląskiego, mazowieckiego i wielkopolskiego, zatem wciąż zaznacza się dominacja „trójkąta przemysłowego". Poza tym obszarem, omawiane tereny występują licznie wokół dużych miast, w szczególności stolic wojewódzkich (ryc. 6, tabela 2). 
Ryc. 6. Liczba terenów przemysłowych wg jednostek ewidencyjnych w Polsce w 2016 r.

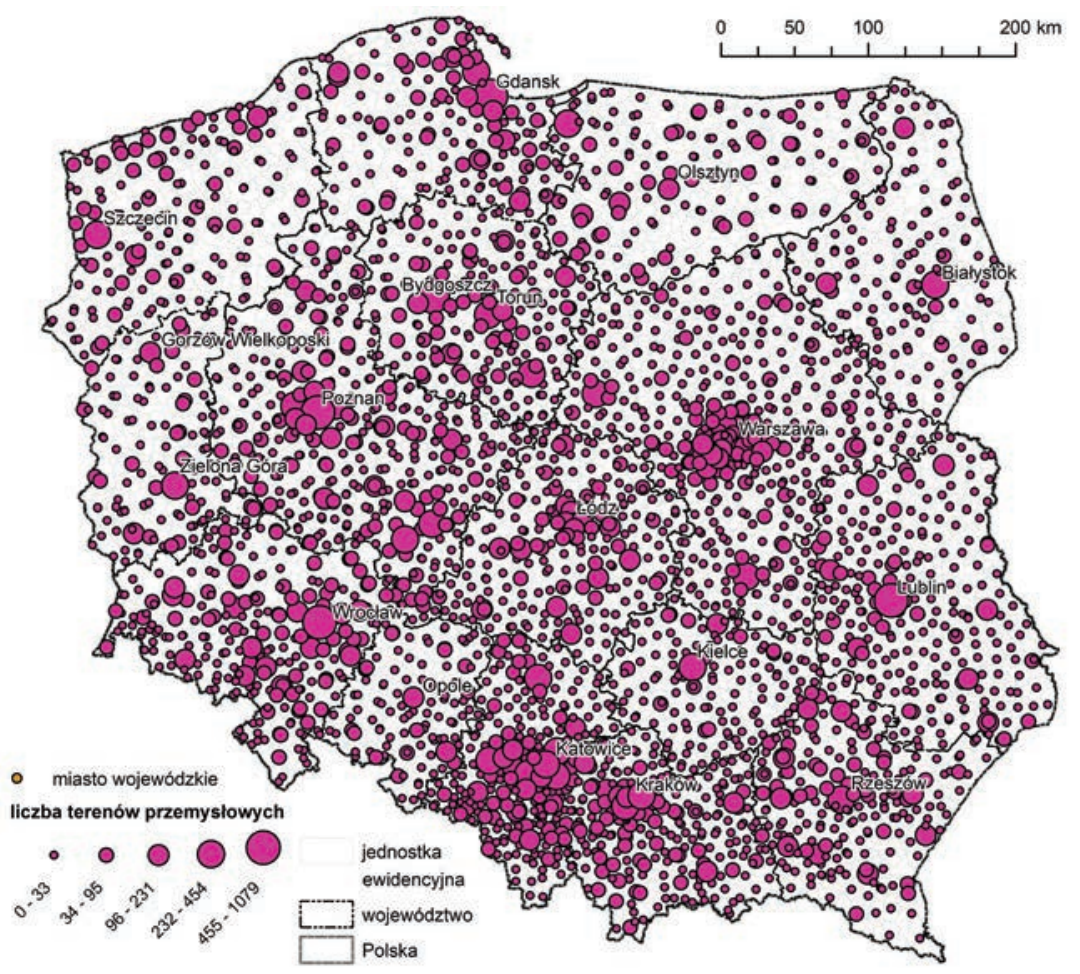

Źródło: opracowanie własne na podstawie BDOT

Tabela 2. Charakterystyka terenów przemysłowych wg wielkości miast w Polsce w 2016 r.

\begin{tabular}{|l|c|c|c|c|c|c|c|c|}
\hline \multicolumn{1}{|c|}{$\begin{array}{l}\text { Wielkość } \\
\text { miasta }\end{array}$} & $\begin{array}{c}\text { Liczba } \\
\text { terenów }\end{array}$ & $\begin{array}{c}\text { Udział } \\
\text { (\%) }\end{array}$ & $\begin{array}{c}\text { Średnia } \\
\text { pow. } \\
\text { (ha) }\end{array}$ & $\begin{array}{c}\text { Odchylenie } \\
\text { standardowe } \\
\text { powierzchni } \\
\text { (ha) }\end{array}$ & $\begin{array}{c}\text { Całkowita } \\
\text { powierzchnia } \\
\text { (ha) }\end{array}$ & $\begin{array}{c}\text { Udział } \\
\text { (\%) }\end{array}$ & $\begin{array}{c}\text { Średni } \\
\text { wskaźnik } \\
\text { zwartości }\end{array}$ & $\begin{array}{c}\text { Odchylenie } \\
\text { standardowe } \\
\text { wskaźnika } \\
\text { zwartości }\end{array}$ \\
\hline $\begin{array}{l}\text { Bardzo małe } \\
(<5000)\end{array}$ & 5858 & 12,4 & 0,78 & 0,51 & 3812,26 & 7,2 & 2,7 & 2,7 \\
\hline Małe & 11886 & 25,2 & 1,03 & 0,62 & 12179,95 & 22,9 & 2,8 & 1,8 \\
\hline Średnie & 16760 & 35,5 & 1,26 & 0,84 & 19438,17 & 36,6 & 3,4 & 4,5 \\
\hline Duże & 12695 & 26,9 & 1,63 & 0,82 & 17750,83 & 33,4 & 3,8 & 1,9 \\
\hline
\end{tabular}

Źródło: opracowanie własne na podstawie BDOT 
Ryc. 7. Zróżnicowanie kształtu terenów przemysłowych wg jednostek ewidencyjnych w Polsce w 2016 r.

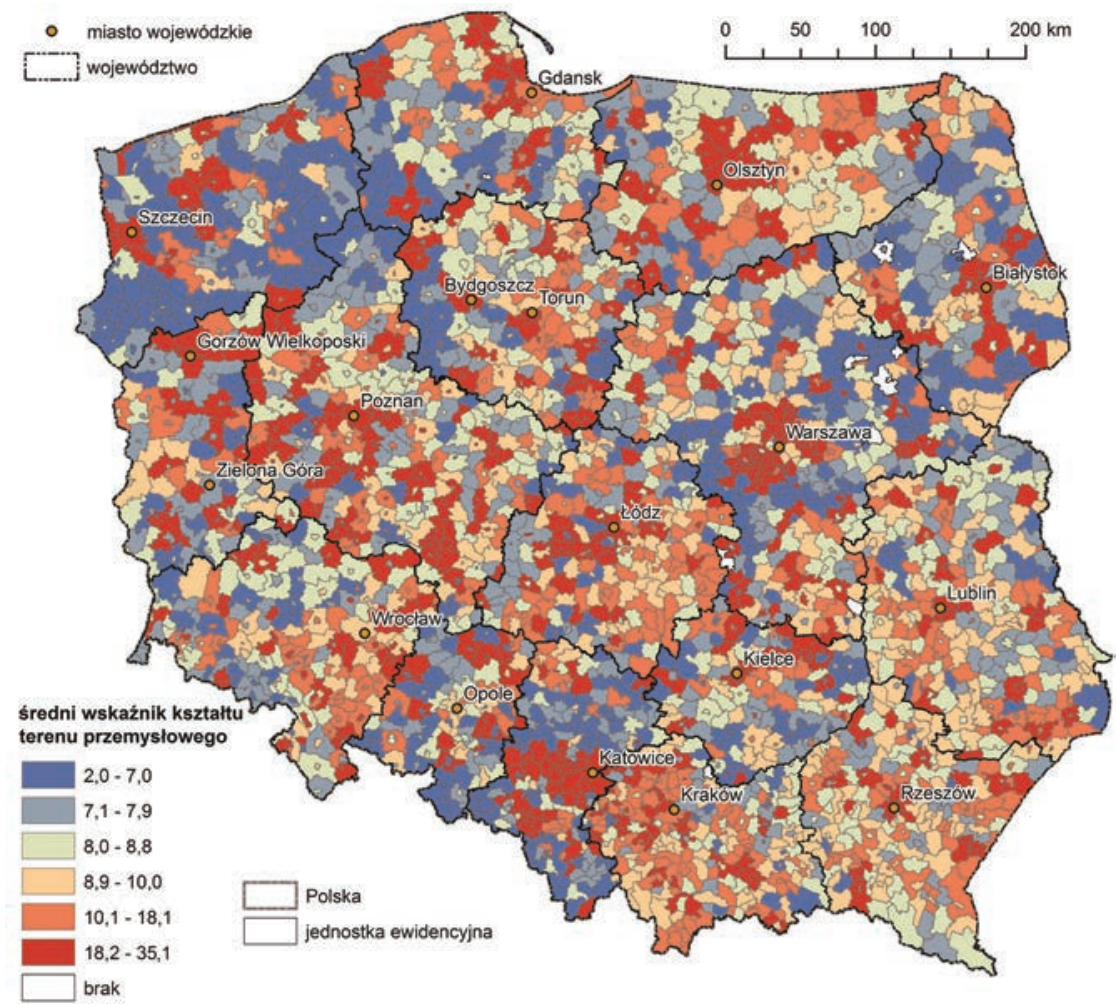

Źródło: opracowanie własne na podstawie BDOT

Wskaźnik zróżnicowania kształtu terenów o funkcji przemysłowej waha się od 2 do 35,1. Jego wartości są uzależnione od średniej powierzchni terenu - wzrastają wraz ze zmniejszaniem się ich powierzchni, maleją z kolei w gminach, gdzie tereny są największe (ryc. 7).

Z kolei wskaźnik zwartości kształtu działek o funkcji przemysłowej w Polsce waha się od 2 do 60,2 (ryc. 8). Niską zwartością charakteryzują się działki położone głównie w zachodniej Polsce oraz w pobliżu dużych miast.

\section{Analiza przypadku województwa mazowieckiego na tle Polski}

Do dalszych analiz wzięto województwo mazowieckie, w którym jak już wspomniano jest jedna z najwyższych powierzchni terenów przemysłowych, w porównaniu z pozostałymi województwami. Dane dotyczące terenów przemysłowych tego obszaru zestawiono z danymi dla całego kraju. W wyniku przeprowadzonych analiz stwierdzono, że średni udział tych terenów w jednostkach ewidencyjnych jest w obu przypadkach jednakowy 


\section{Ryc. 8. Zróżnicowanie zwartości terenów przemysłowych wg jednostek ewidencyjnych w Polsce w 2016 r.}

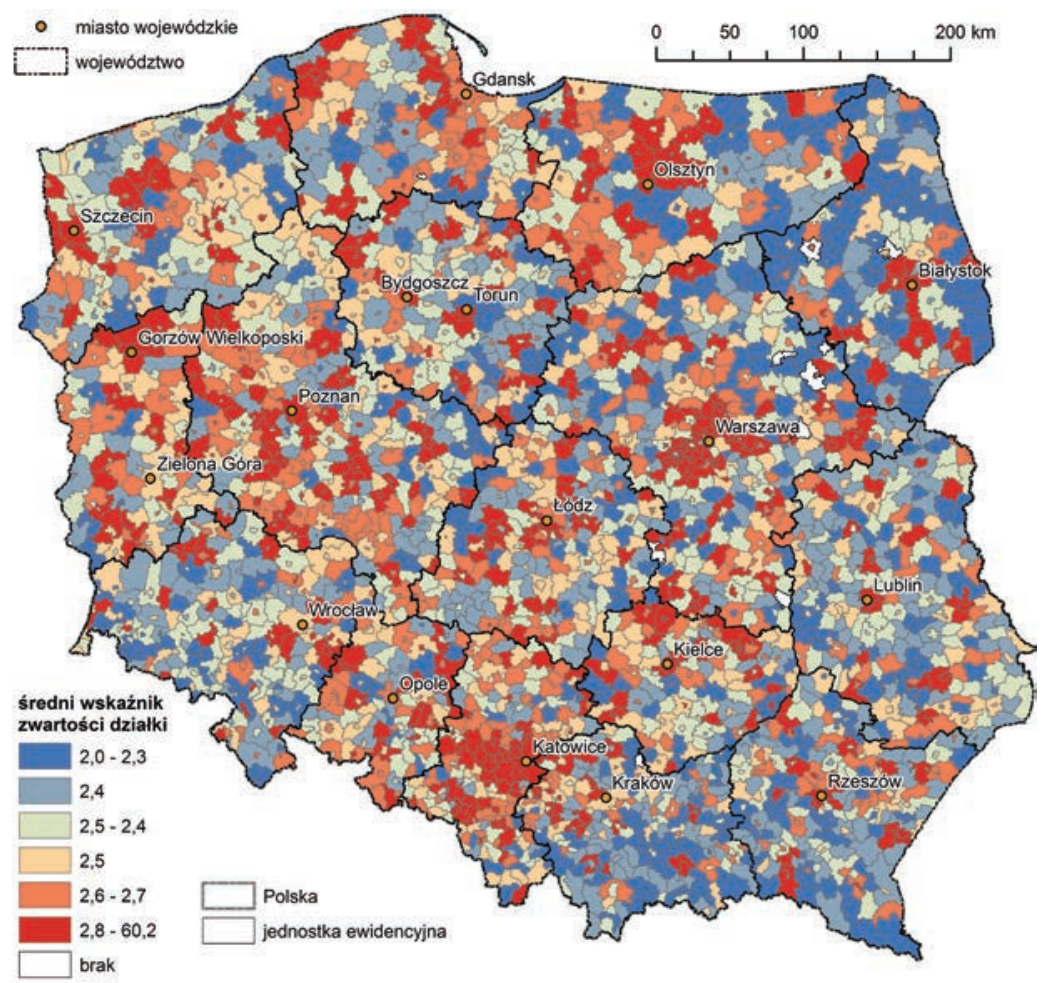

Źródło: opracowanie własne na podstawie BDOT

i wynosi $0,8 \%$. Średnia powierzchnia analizowanych terenów jest natomiast nieznacznie wyższa dla województwa mazowieckiego, gdzie wynosi ok. 0,9 ha, zaś w przypadku Polski jest to wartość - 0,8 ha. Jednak w badanym regionie średnia liczba omawianych obszarów, przypadająca na jednostkę ewidencyjną jest mniejsza, co wskazuje, że tereny te są tu po prostu większe. Ma to również swoje odzwierciedlenie w średniej wartości wskaźnika zróżnicowania kształtu terenów o funkcji przemysłowej - w Polsce wynosi on 8,5, zaś W województwie mazowieckim 4,3 (jego wartości są uzależnione od średniej powierzchni terenu - wzrastają wraz ze zmniejszaniem się ich powierzchni, maleją z kolei w gminach, gdzie tereny są największe). Z kolei średni wskaźnik zwartości kształtu działek o funkcji przemysłowej ma wartość podobną w obu analizowanych przypadkach, zaś różnice zaznaczają się w jego wartościach maksymalnych - jest on prawie dwukrotnie wyższy dla Polski, a jego wartość wynosi 60,2 (tabela 3). Wpływ na to ma fakt, że najwięcej terenów przemysłowych $\mathrm{w}$ analizowanym województwie znajduje się $\mathrm{w}$ bezpośrednim sąsiedztwie Warszawy. 
Tabela 3. Charakterystyka terenów przemysłowych województwa mazowieckiego na tle Polski

\begin{tabular}{|l|c|c|c|c|c|c|}
\cline { 2 - 7 } \multicolumn{1}{c|}{} & \multicolumn{4}{c|}{ Polska } \\
\hline & minimum & średnia & maksimum & minimum & średnia & maksimum \\
\hline $\begin{array}{l}\text { Udział powierzchni terenów } \\
\text { przemysłowych (\%) }\end{array}$ & 0 & 0,8 & 13,6 & 0 & 0,8 & 9,1 \\
\hline $\begin{array}{l}\text { Odchylenie standardowe } \\
\text { powierzchni } \\
\text { terenów przemysłowych (ha) }\end{array}$ & 0 & 1,14 & 40,91 & 0 & 1,11 & 6,65 \\
\hline $\begin{array}{l}\text { Powierzchnia terenu } \\
\text { przemysłowego (ha) }\end{array}$ & 0 & 0,82 & 12,09 & 0 & 0,89 & 12,09 \\
\hline $\begin{array}{l}\text { Liczba terenów przemysłowych } \\
\text { Wskaźnik kształtu terenu prze- } \\
\text { mysłowego }\end{array}$ & 0 & 30,8 & 1079 & 0 & 27,4 & 344 \\
\hline Wskaźnik zwartości działki & 2 & 8,5 & 35,1 & 2 & 4,3 & 10,5 \\
\hline
\end{tabular}

Źródło: opracowanie własne na podstawie BDOT

\section{Analiza przypadku województwa mazowieckiego}

W dalszej części pracy szczegółowym analizom poddano tereny przemysłowe województwa mazowieckiego. Jak już wspomniano, w tym przypadku najwięcej działek zajętych pod tę funkcję przypada na tereny położone w najbliższym sąsiedztwie Warszawy [Rosik 2013] oraz pojedyncze gminy na wchodzie i południowym zachodzie od stolicy kraju (ryc. 9).

Z kolei udział terenów przemysłowych w powierzchni działki jest najwyższy w gminach położonych na północ od Warszawy oraz w południowo-zachodniej części województwa mazowieckiego (ryc. 10).

Największą średnią powierzchnię terenu przemysłowego mają gminy położone w szczególności w zachodniej części badanego województwa (ryc. 11). Z kolei działki zajęte pod tę funkcję są największe głównie na zachód od stolicy kraju oraz w północnej części województwa mazowieckiego (ryc. 12). W przypadku działalności przemysłowej, wielkość działki może mieć duże znaczenie. Dla tak terenochłonnej formy aktywności gospodarczej czynnikiem lokalizacji jest niewielki stopień rozdrobnienia gruntów. Ułatwia to zarządzanie przedsiębiorstwem poprzez ograniczenie barier własnościowych czy w rozwoju przestrzennym działalności. Średni udział terenów przemysłowych w granicach działki, w której on funkcjonuje, pozwala wnioskować o znacznym potencjale dalszego rozwoju tej formy użytkowania ziemi. Oczywiście przyjmując brak barier w postaci zapisów lokalnego prawa przestrzennego. 
Ryc. 9. Liczba działek przypadających na teren przemysłowy wg jednostek ewidencyjnych w województwie mazowieckim w 2016 r.

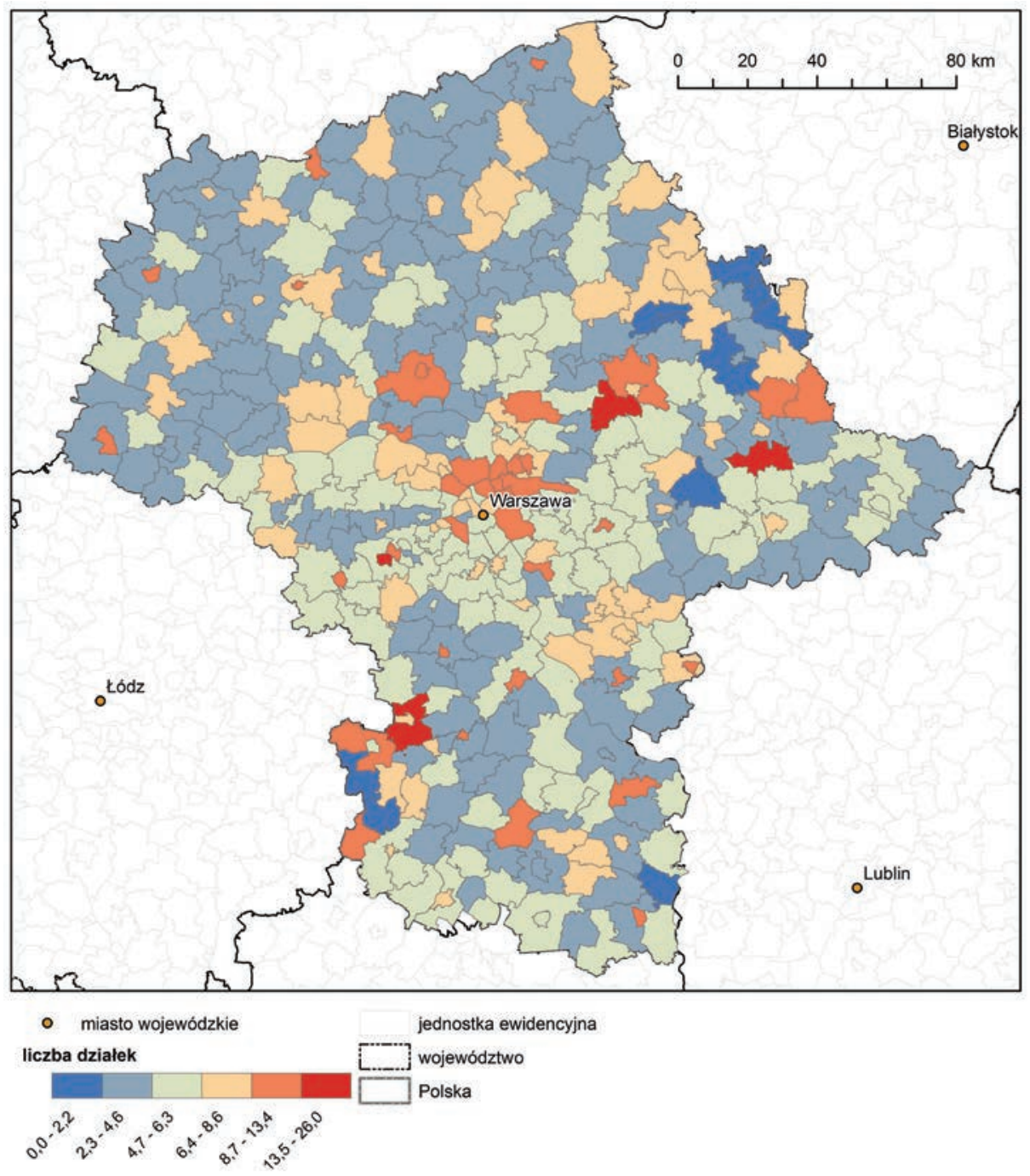

Źródło: opracowanie własne na podstawie BDOT i LPIS

\section{Wnioski}

Jednym z celów artykułu była analiza rozmieszczenia i oceny zróżnicowania terenów przemysłowych w Polsce pod względem ich cech geometrycznych. W ujęciu przestrzennym, przeprowadzone badania wskazują że rozmieszczenie terenów związanych z działalnością przemysłową w Polsce cechuje się dużym zróżnicowaniem. Zdecydowanie największa powierzchnia terenów przemysłowych znajduje się w województwie śląskim, mazowieckim i wielkopolskim. Przeciętna powierzchnia terenów przemysłowych jest najwyższa 
Ryc. 10. Udział terenu przemysłowego w powierzchni działki nim objętej wg jednostek ewidencyjnych w województwie mazowieckim w 2016 r.

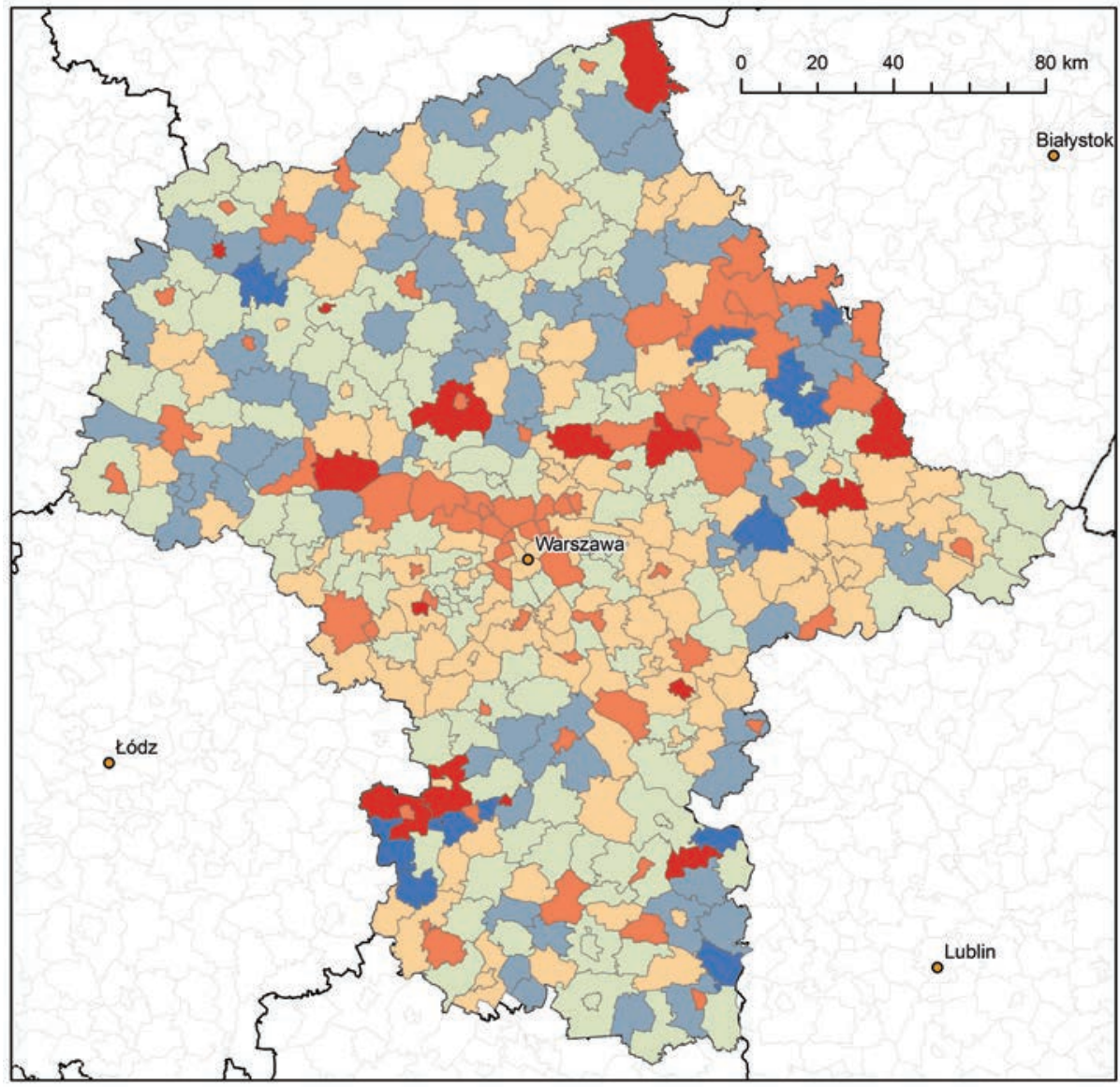

- miasto wojewódzkie

jednostka ewidencyjna

udział w powierzchni działki [\%]

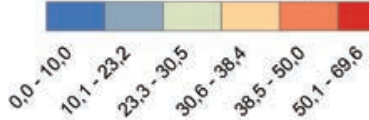

województwo

Polska

Źródło: opracowanie własne na podstawie BDOT i LPIS

w aglomeracji górnośląskiej, w województwie mazowieckim oraz w województwie zachodniopomorskim. Ponadto, zaznacza się różnica pomiędzy zachodnią, a wschodnią Polską. W części zachodniej kraju, tereny, na których prowadzona jest działalność przemysłowa są zdecydowanie większe. Liczba terenów przemysłowych jest najwyższa w szczególności w gminach województwa śląskiego, mazowieckiego i wielkopolskiego. 


\section{Ryc. 11. Średnia powierzchnia terenu przemysłowego na działce nim objętej wg jednostek ewidencyjnych w województwie mazowieckim w 2016 r.}
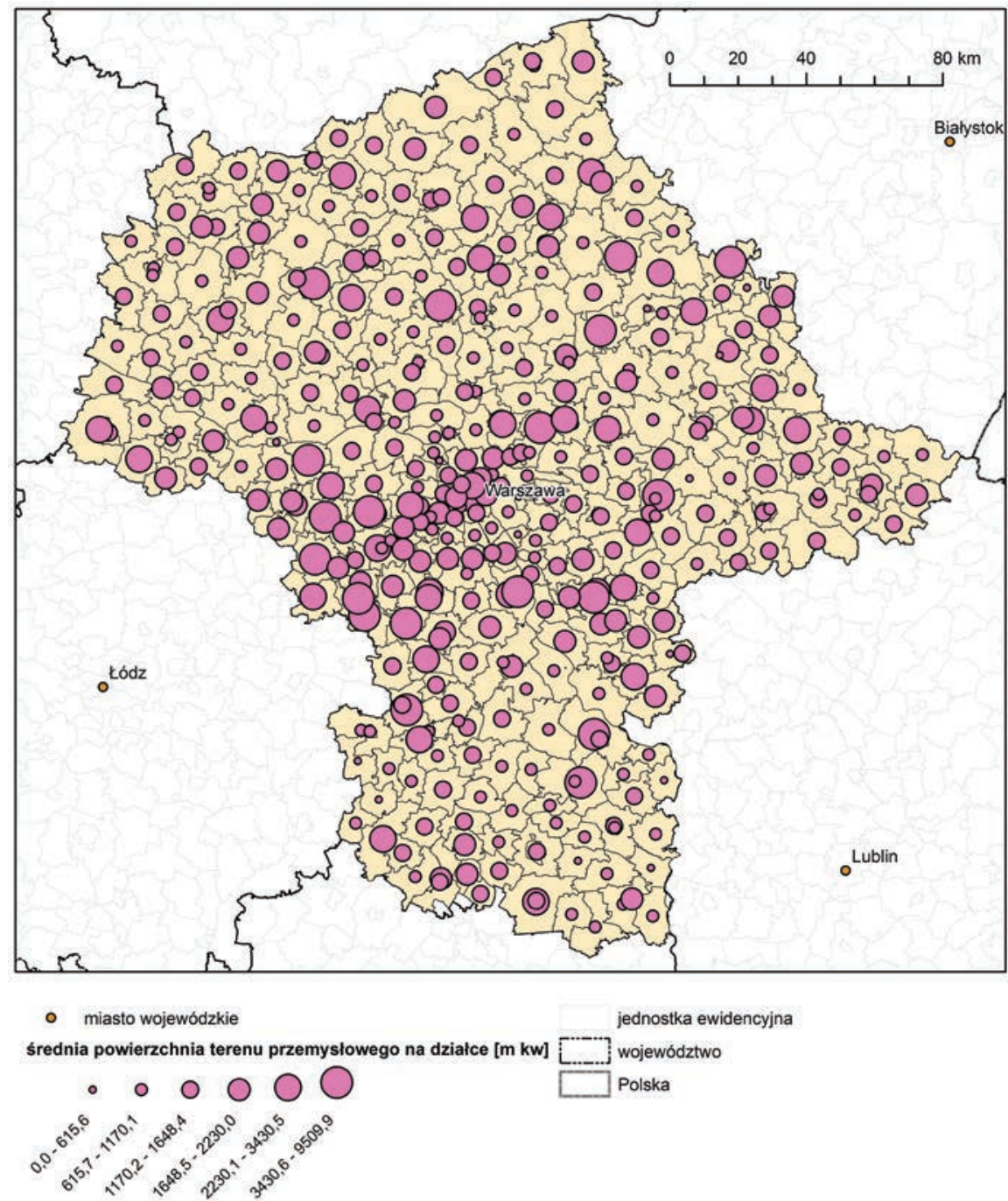

Źródło: opracowanie własne na podstawie BDOT i LPIS

Z kolei drugi cel odnosił się do porównania cech geometrycznych omawianych terenów w skali kraju, z tymi dla województwa mazowieckiego. W wyniku przeprowadzonych badań, stwierdzono, że różnice są dostrzegalne w przypadku średniej powierzchni terenów przemysłowych - jest ona nieznacznie wyższa dla województwa mazowieckiego, gdzie wynosi ok. 0,9 ha oraz średniej liczby terenów przemysłowych - jest ona niższa w przypadku badanego regionu. Wartości te mają swoje odzwierciedlenie również w przypadku średniej 
Ryc. 12. Średnia powierzchnia działki objętej terenem przemysłowym wg jednostek ewidencyjnych w województwie mazowieckim w 2016 r.

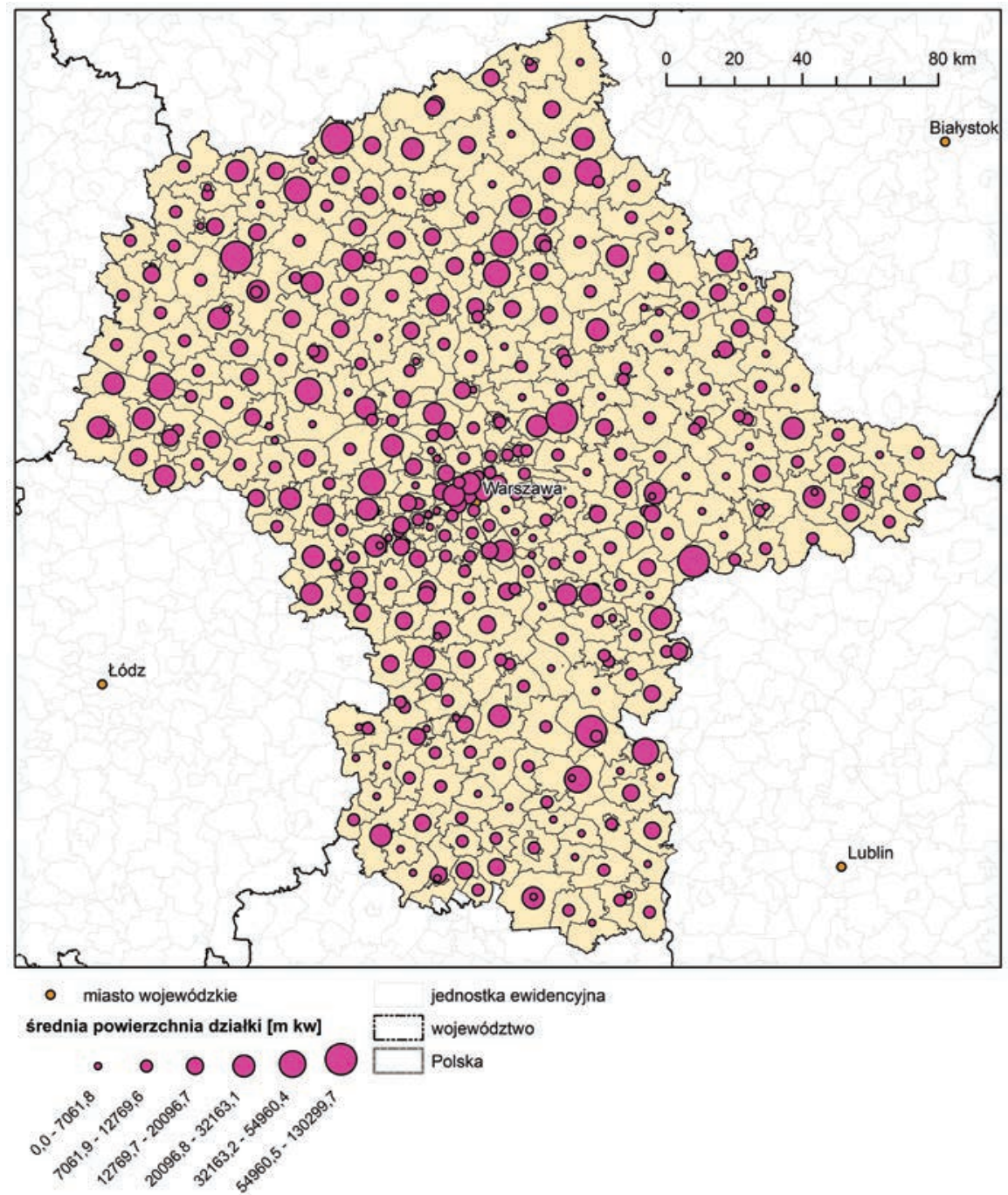

Źródło: opracowanie własne na podstawie BDOT i LPIS

wartości wskaźnika zróżnicowania kształtu badanych terenów - jest on prawie dwukrotnie niższy dla analizowanego regionu. $Z$ kolei średni udział terenów przemysłowych oraz średnia wartość wskaźnika zwartości działki są w obu przypadkach na porównywalnym poziomie.

Dlatego też należy podkreślić, że pomimo znacznych zmian dotyczących wszystkich niemalże aspektów funkcjonowania przemysłu w granicach Polski, jakie wiązały sięz wejściem $\mathrm{w}$ realia wolnorynkowe, to w ujęciu przestrzennym wciąż zaznacza się dominacja „trójkąta 
przemysłowego". Zmiany czynników lokalizacji tak niemobilnej działalności człowieka jaką jest przemysł, z jednej strony wydają się na tyle nieznaczne, że nie przekładają się na zmianę rozmieszczenia obszarów jego ciążenia. Z drugiej zaś, zmiany owych czynników mogą być wyraźne, jednak „stare” lokalizacje również doskonale spełniają „nowe” wymagania.

Przeprowadzone badanie wskazuje na potrzebę realizacji kolejnych analiz, ale na jeszcze niższym poziomie przestrzennym i uwzględniającym kolejne zmienne. Włączenie do badania danych na temat sposobu zagospodarowania sąsiedztwa terenów przemysłowych, ich formy własności czy wartości (na podstawie cen transakcyjnych) dałoby szansę na wskazanie kolejnych prawidłowości. Interesującym wątkiem byłoby również przeanalizowanie wskazanych zmiennych w ujęciu dynamicznym. Tutaj jednak szczególnie zaznaczać się będzie kluczowy w tego typu analizach problem braku danych źródłowych. Powyższy artykuł posłużyć może za wprowadzenie do dalszych, uszczegółowionych analiz, jako etap wyznaczenia obszarów, na których ogniskować powinny się dalsze działania.

\section{Literatura}

Borowska-Stefańska M., Leśniewska-Napierała K., Wiśniewski S., 2017 a, Spatial variation in size and shape of land plots in Mazowieckie voivodeship, w recenzji.

Borowska-Stefańska M., Modrzejewska K., Wiśniewski S.,2017 b, Differentiation of residential development in Poland's provincial capitals, $\mathrm{w}$ recenzji.

Borowska-Stefańska M., Wiśniewski S., 2017, Changes in transport accessibility as a result of flooding: a case study of the Mazovia Province (Eastern Poland), Environmental Hazards. Human and Policy Dimensions, s. 1-28.

Cudny W., 2011, Model przemian miasta postsocjalistycznego - przykład Łodzi, Studia Miejskie, 4, s. 153-159.

Domański B., 2006, Polski przemyst na tle przemystu Europy Środkowej i Wschodniej, Prace Komisji Geografii Przemysłu Polskiego Towarzystwa Geograficznego, 8, s. 27-36.

Fierla I., 1984, Geografia przemystu Polski, PWE, Warszawa.

Fierla I., 1987, Lokalizacja przemystu, PWE, Warszawa.

Gierańczyk W., Stańczyk A., 2001, Okręgi przemysłowe w Polsce u progu XXI wieku, Prace Komisji Geografii Przemysłu Polskiego Towarzystwa Geograficznego, 3, s. 61-69.

Kawalec W., 1970, Wybrane problemy struktury przestrzennej przemystu (na podstawie materiałów spisu przemystowego 1965 r.), Biuletyn KPZK PAN, 56, Warszawa. 
Kryńska E.(red.), 2000, Polskie Specjalne Strefy Ekonomiczne - zamierzenia i efekty, Europejski Instytut Rozwoju Regionalnego i Lokalnego UW, Warszawa.

Leszczycki S., Grzeszczak J., Kukliński A., Zajda Z., 1964, Z badań nad problematyka przestrzenna przemysłu Polski, Biuletyn KPZK PAN, 32, Warszawa.

Liszewski S., 2004, Przemiany struktury przestrzennej aglomeracji przemystowej w okresie transformacji ustrojowej (przykład tódzkiej aglomeracji miejskiej), [w:] J. Słodczyk (red.), Przemiany struktury przestrzennej miast w sferze funkcjonalnej i społecznej, Wydawnictwo Uniwersytetu Opolskiego, Opole.

Marczyńska-Witczak E., 2001, Procesy dezindustrializacji przestrzennejw latach dziewiećdziesiatych na przykładzie Łodzi, Prace Komisji Geografii Przemysłu Polskiego Towarzystwa Geograficznego, 2, s. 41-48.

Marczyńska-Witczak E., Starzyńska W., 2002, Procesy dezindustrializacji w aglomeracji łódzkiej w latach dziewięćdziesiątych, Acta Universitatis Lodziensis. Folia Geographica SocioOeconomica, 4, s. 25-32.

Misztal S., 1970, Przemiany w strukturze przestrzennej przemystu na ziemiach polskich $w$ latach 1860-1965, Studia KPZK PAN, 31, Warszawa.

Pakuła L., 1978, Problemy teoretyczno-badawcze form koncentracji przestrzennej przemystu, Folia Geographica Series Geographica-Oeconomica, 6.

Rachwał T., 2008, Problematyka badawcza funkcjonowania przedsiębiorstw przemystowych, Prace Komisji Geografii Przemysłu Polskiego Towarzystwa Geograficznego, 11, s. 53-85.

Rachwał T., 2010, Struktura przestrzenna i działowa przemystu Polski na tle Unii Europejskiej $w$ dwudziestolecie rozpoczęcia procesów transformacji systemowej, Prace Komisji Geografii Przemysłu Polskiego Towarzystwa Geograficznego, 16, s. 105-124.

Rosik P., 2013, Nieruchomości gruntowe w województwie mazowieckim, Mazowsze Studia Regionalne, 13, s. 65-79.

Secomski K., 1956, Wstęp do rozmieszczenia sił wytwórczych, Polskie Wydawnictwa Gospodarcze, Warszawa.

Smętkowski M., 2008, Rola specjalnych stref ekonomicznych w ksztattowaniu struktury przestrzennej przemystu w Polsce, Prace Komisji Geografii Przemysłu Polskiego Towarzystwa Geograficznego, 10, s. 204-216. 
Trojak A., Wiedermann K., 2009,.Specjalne strefy ekonomiczne i strefy przemysłowe w ksztattowaniu rozwoju gospodarczego regionów na przykładzie Polski i Czech, Prace Komisji Geografii Przemysłu Polskiego Towarzystwa Geograficznego, 12, s. 133-143.

Trzciński R., Stasiowski J., Konieczna-Sałamatin J., Skórska P., Bienias S., Weremiuk A., 2016, Wptyw specjalnych stref ekonomicznych na zatrudnienie. Ocena Skutków Regulacji ex post ustawy o specjalnych strefach ekonomicznych z dnia 20 października 1994 roku (Dz.U. z 1994 r. nr 123 poz. 600 z późn. zm.). Raport końcowy, Warszawa.

Zioło Z., 1971, Stan badań nad problemem struktury przestrzennej przemystu i jej form koncentracji, Materiały Informacyjne WKPG w Krakowie, 40, Prace Geograficzne, 5, Kraków.

\section{Strony internetowe}

www.stat.gov.pl [dostęp dnia: 19.07.2017 r.] 


\section{Spatial differentiation of industrial areas in the Mazovia region and Poland}

\section{ABSTRACT}

The article provides an analysis of the distribution of industrial areas in Poland and an assessment of their diversification in terms of geometric features. The authors calculated, for instance, the surface and number of industrial areas in individual regions and cadastral units, their share in individual cadastral units, the average surface according to cadastral units, indexes of parcel shape differentiation and density. The data referring to the areas' geometrical features at the national level was compared with that of Mazovia. Data on industrial areas in Poland was acquired from the Database of Topological Objects (BDOT) obtained from the Geodesic and Cartographic Documentation Centre in Warsaw. Layers with parcels were taken, in turn, from the Land Parcel Identification System (LPIS).

Industrial areas in Poland were created in various circumstances and periods. They are also diversified in terms of their range, development, activity type and relations with the economic surroundings. From the spatial perspective, the conducted research shows that the distribution of areas connected with industrial activity in Poland is characterized by considerable differentiation. The markedly largest surface of industrial areas can be found in the regions of Silesia, Mazovia and Greater Poland. The average surface of an industrial area is largest in the Upper Silesia agglomeration, the Mazovia region and the Zachodniopomorskie region. There is also a distinct difference between western and eastern Poland. In the western part of the country areas where industrial activity is conducted are appreciably bigger. The number of industrial areas is the highest in particular in the municipalities of the Silesian, Mazovian and Greater Poland regions.

Differences were also identified when comparing data concerning industrial areas in Poland as a whole with data from Mazovia. The average surface of industrial areas turned out to be slightly higher in Mazovia, where it is approx. $0.9 \mathrm{ha}$, while the average number of industrial areas in the region is lower than the national average. These values are also reflected in the average value of the indicator of parcel shape differentiation which is almost two times lower in the analyzed region. On the other hand, there is little difference in terms of the average share of industrial areas and the average indicator of parcel shape density.

Key words: Poland, industrial areas, geography of industry, GIS

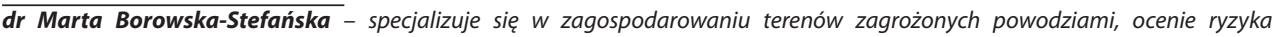
powodziowego i zarządzaniu nim, mobilnościq przestrzennq, członek PTG, sekretarz redakcji czasopisma Biuletyn Uniejowski, sekretarz Ośrodka Badawczego Europejskiej Polityki Przestrzennej i Rozwoju Lokalnego, kontakt do autorki: Instytut Zagospodarowania Środowiska i Polityki Przestrzennej, Wydział Nauk Geograficznych Ut, ul. Kopcińskiego 31, 90-142 Łódź, e-mail: marta.borowska@geo.uni.lodz.pl

Marta Borowska-Stefańska, PhD, specializes in development of flood prone areas, flood risk assessment and management, spatial mobility; she is a member of the Polish Geographical Society (PTG), editorial assistant of the Uniejów Bulletin, secretary of the Research Centre for European Spatial Policy and Local Development (Ośrodek Badawczy Europejskiej Polityki Przestrzennej i Rozwoju Lokalnego).

dr Szymon Wiśniewski - prowadzi badania z zakresu planowania i rozwoju infrastruktury transportowej, geografii transportu, logistyki miejskiej, dostępności, inteligentnych systemów transportowych, członek Centrum Technologii Bezpieczeństwa w Logistyce, sekretarz redakcji czasopisma Biuletyn Szadkowski, sekretarz Ośrodka Badawczego Europejskiej Polityki Przestrzennej i Rozwoju Lokalnego, członek Komisji Geografii Komunikacji PTG, kontakt do autora: Instytut Zagospodarowania Środowiska i Polityki Przestrzennej, Wydział Nauk Geograficznych Ut, ul. Kopcińskiego 31, 90-142 Łódź, e-mail: szymon.wisniewski@geo.uni.lodz.pl

Szymon Wiśniewski, PhD, does research in transport infrastructure planning and development, geography of transport, urban logistics, accessibility of smart transport systems, He is a member of the Centre for Security Technologies in Logistics, editorial assistant of the Szadek Bulletin, secretary of the Research Centre for European Spatial Policy and Local Development (Ośrodek Badawczy Europejskiej Polityki Przestrzennej i Rozwoju Lokalnego), member of Transport Geography Papers of Polish Geographical Society.
} 